\title{
Makna Pelekatan Sidik Jari Dalam Minuta Akta Notaris
}

\author{
Duhita Sresti Abhirama \\ Universitas Airlangga \\ restiabhirama@gmail.com
}

\begin{abstract}
Notary as a general official in carrying out his office always based on the authority, obligations and restrictions set forth in UUJN. One of the obligations of a notary is to attach fingerprints in every minuta deed made. Some time ago, the notary was confused which meant the fingerprints were the thumb or 10 (ten) fingers. The purpose in writing is to examine and analyze the meaning of fingerprint attachment in minuta deed. Research method in writing is normative juridical with statute approach and conceptual approach. The results showed that fingerprint attachment does not affect the authenticity of notary deed. Terms of authentic deeds have been regulated in Article $1868 \mathrm{BW}$ and Article 38 UUJN. The aforementioned obligation aims at protecting the Notary from denial of signature signature and serves as additional proof that the confrontation is right with the Notary. If the responders refuse to attach their fingerprints, the notary must provide a reason for the fingerprint attachment to the cover. Despite the deed without any fingerprints, the deed remains authentic and not degraded to the deed under the hand. Notary if the attachment is not attached, the notary will get sanction from the Supervisory Board.
\end{abstract}

Keywords: Fingerprint, Minuta Deed, Notary

\begin{abstract}
Abstrak
Notaris sebagai pejabat umum dalam menjalankan jabatannya senantiasa berdasarkan kewenangan, kewajiban dan larangan yang diatur dalam UUJN. Salah satu kewajiban notaris adalah melekatkan sidik jari penghadap dalam setiap minuta akta yang dibuat. Beberapa waktu lalu, notaris mengalami kebingungan yang dimaksud sidik jari apakah ibu jari atau 10 (sepuluh) jari tangan. Tujuan dalam penulisan adalah untuk mengkaji dan menganalisis makna perlekatan sidik jari dalam minuta akta. Metode penelitian dalam penulisan yaitu yuridis normatif dengan pendekatan undang-undang dan pendekatan konseptual. Hasil penelitian didapatkan bahwa pelekatan sidik jari tidak berpengaruh otentisitas akta notaris. Syarat akta otentik telah diatur dalam Pasal 1868 BW dan Pasal 38 UUJN. Kewajiban tersebut bertujuan melindungi Notaris dari tindakan penyangkalan tandatangan penghadap dan berfungsi sebagai bukti tambahan bahwa penghadap benar berhadapan dengan Notaris. Jika para penghadap menolak melekatkan sidik jari, notaris harus memberi alasan penolakan pelekatan sidik jari pada penutup aktanya. Meskipun akta tanpa ada sidik jari penghadap, akta tetap otentik dan tidak terdegradasi menjadi akta dibawah tangan. Notaris apabila tidak melekatkan sidik jari penghadap, maka notaris akan mendapatkan sanksi dari Majelis Pengawas.
\end{abstract}

Kata Kunci: Sidik Jari, Minuta Akta, Notaris 


\section{Pendahuluan}

Dewasa ini, iklim dunia usaha maupun bisnis semuanya serba kompetitif, peran notaris menjadi sangat penting sehingga mau tak mau, notaris pun harus ikut berkompetisi dalam memberikan pelayanannya. Notaris harus senantiasa selalu memperluas wawasan dan pengetahuannya baik dalam bidang bisnis maupun peraturan perundang-undangan. Alasannya, notaris dilahirkan karena tuntutan masyarakat itu sendiri guna memperoleh perlindungan dan jaminan hukum atas transaksi yang mereka lakukan. Walaupun kompetitif, notaris harus tetap bekerja sesuai dengan koridor hukum dan etika jabatan notaris sehingga akta yang dihasilkan benar-benar otentik dan memiliki kekuatan pembuktian yang sempurna.

$$
\text { Peraturan tentang Jabatan }
$$

Notaris baru-baru ini telah mengalami perubahan dengan berlakunya Undang-Undang No. 2 Tahun 2014 terkait Perubahan atas Undang-Undang No. 30 Tahun 2004 tentang Jabatan Notaris (UUJN) yang dianggap sudah ketinggalan jaman.
Salah satu yang mengganjal dengan diundangkannya undang-undang yang baru ini adalah menghidupkan kembali ketentuan pelekatan sidik jari (cap jari) penghadap pada minuta akta yang dibuat oleh notaris. Pasal 16 ayat (1) huruf c UUJN menyatakan bahwa "Dalam menjalankan jabatannya, Notaris wajib: melekatkan surat dan dokumen serta sidik jari penghadap pada Minuta Akta".

Ketentuan baru dalam kewajiban Notaris ini tentu mendapat sambutan. Sisi bisnis, terutama perbankan tak sedikit yang melihat ketentuan tersebut lebih banyak merepotkan mereka karena tidak praktis. Dilihat dari sisi hukum, undang-undang tidak mungkin dapat seluruhnya memberikan ketentuan yang rinci mengenai penerapan dari undangundang itu sendiri. Tak heran, sering terjadi kesalahan penafsiran di lapangan. Aturan tentang pelekatan sidik jari dapatlah diterapkan apabila ada penjelasan. Namun, terkait dengan penerapan pelekatan sidik jari, penjelasan tersebut tidak kita temukan dalam UUJN tersebut dan hanya dinyatakan "cukup jelas". 
Artinya, ketentuan pelekatan sidik jari sudah terang dan tidak perlu dijabarkan lagi. Oleh karena itu, penting untuk mengkaji dan menganalisis tentang makna pelekatan sidik jari penghadap dalam minuta akta notaris.

\section{Metode Penelitian}

Metode penelitian sangat diperlukan dalam penulisan ilmiah, agar analisis yang dilakukan terhadap obyek studi dapat dijalankan sesuai dengan prosedur yang benar sehingga kesimpulan akhir yang diperoleh adalah tepat serta dapat dipertanggungjawabkan secara ilmiah (Marzuki, 2010: 35). Metode ilmiah yang digunakan dalam penulisan ini adalah suatu metode yang terarah dan sistematis sebagai cara untuk menemukan, mengembangkan, dan menguji kebenaran.. Metode Penelitian yang dimaksud meliputi 4 (empat) aspek yaitu tipe penelitian, pendekatan masalah, bahan hukum, dan analisis bahan hukum (Marzuki, 2010: 190).

Penggunaan metode di dalam melakukan suatu penelitian karya ilmiah dapat digunakan untuk menggali, mengolah, dan merumuskan bahan-bahan hukum yang diperoleh sehingga mendapatkan kesimpulan yang sesuai dengan kebenaran ilmiah untuk menjawab isu yang dihadapi. Sehingga pada akhirnya dapat ditarik

\section{a) Tipe Penelitian}

Tipe penelitian yang digunakan dalam penulisan jurnal yaitu yuridis normatif (legal research) merupakan penelitian yang difokuskan pada penerapan kaidah-kaidah atau norma-norma hukum positif yang terdapat dalam undang-undang, yurisprudensi (case law), atapun kontrak (Marzuki, 2010: 104).

\section{b) Pendekatan Masalah}

Penelitian hukum memiliki beberapa pendekatan yang dapat digunakan peneliti dalam mengupas isu hukum antara lain pendekatan perundang-undangan

(statute approach), pendekatan konseptual (conceptual approach).

Pendekatan perundangundangan (statute approach) dilakukan dengan menelaah semua undang-undang dan regulasi yang bersangkut paut dengan isu hukum yang sedang ditangani. (Marzuki, 
2010 : 133). Pendekatan konseptual (conceptual approach) yaitu beranjak dari pandangan-pandangan dan doktrin-doktrin yang berkembang dalam ilmu hukum. (Marzuki, 2010: 178).

\section{c) Sumber Bahan Hukum \\ 1) Bahan Hukum Primer}

Bahan hukum primer merupakan bahan hukum yang bersifat autoritatif yang artinya mempunyai otoritas. Bahan hukum primer terdiri dari peraturan perundang-undangan, catatan-catatan resmi atau risalah dalam pembuatan undang-undang dan putusan-putusan hakim (yuriprudensi) (Marzuki, 2010: 141).

\section{2) Bahan Hukum Sekunder}

Bahan hukum sekunder berupa semua publikasi tentang hukum yang bukan merupakan dokumendokumen resmi (Marzuki, 2010: 98). Publikasi tentang hukum meliputi buku-buku, kamus-kamus hukum, jurnal-jurnal hukum, dan komentarkomentar atas putusan pengadilan. Pada penulisan ini, bahan hukum sekunder yang digunakan adalah buku-buku teks yang berkaitan dengan isu hukum yang menjadi pokok permasalahan.

\section{3) Bahan Non Hukum}

Disamping sumber-sumber penelitian yang berupa bahan-bahan hukum, peneliti hukum juga dapat menggunakan bahan-bahan non hukum apabila dipandang perlu. Bahan-bahan non hukum dapat berupa buku-buku mengenai Ilmu Politik, Ekonomi, Sosiologi, Filsafat, Kebudayaan, atau laporan-laporan penelitian non hukum dan jurnaljurnal non hukum sepanjang mempunyai relevansi dengan topik penelitian yang sedang dikaji (Marzuki, 2010: 143).

\section{Pembahasan}

Kewajiban Notaris Melekatkan Sidik Jari Para Penghadap Dalam Minuta Akta Notaris

Menurut KBBI, frasa 'sidik jari' sebagai kata benda dapat berarti rekaman jari atau cap jempol (Kamus Besar Bahasa Indonesia, 2008: 1665). Dari pengertian ini, dapat diinterpretasikan bahwa yang dimaksud sebagai "sidik jari” adalah rekaman jari atau cap jempol. Apakah itu harus sepuluh jari atau satu jari saja ataupun apakah itu cap jempol kiri atau kanan-kiri, semuanya berpulang pada masalah 
cara menginterpretasinya. Secara luas, maka sidik jari dapat berarti 10 (sepuluh) jari semuanya. Secara sempit, dapat berarti salah satu jari atau jempol saja, mau pilih yang mana dipersilahkan. Di dalam UUJN diterangkan bahwa pelekatan sidik jari para penghadap dalam minuta akta ialah suatu kewajiban bagi setiap notaris. Menjadi pertanyaan adalah yang dimaksud dengan pelekatan sidik jari yang mana secara normatif belum dijelaskan oleh pembentuk UUJN sehingga mengakibatkan Notaris, para penghadap, bahkan majelis pengawas daerah pun mengalami kebingungan.

Kebingungan Notaris dalam melekatkan sidik jari para penghadap dalam minuta akta dalam praktek terjadi karena ketidakjelasan mekanisme penggunaan sidik jari tersebut. Sedangkan, Penjelasan Pasal 16 ayat (1) huruf c UUJN hanya mengatakan cukup jelas. Fardian menuturkan banyak notaris yang kebingungan jari apa yang sidiknya harus diambil dan berapa banyak sidik jari yang diperlukan dari tiap-tiap penghadap. Berbagai macam penafsiran muncul terkait kewajiban Notaris dalam melekatkan sidik jari pada minuta akta. Ada yang mengatakan bahwa penghadap diharuskan membubuhkan kesepuluh sidik jarinya, di sisi lain ada pula yang mengatakan cukup sidik jari jempol saja.

Keberagaman interpretasi dalam dunia hukum memang sudah ada sejak lama, perbedaan pandangan atas sebuah aturan terkadang bukanlah suatu hal yang tabu. Bila kita ingat pelajaran Pengatar Ilmu Hukum, kita diajarkan bahwa definisi hukum itu ibarat beberapa orang buta memegang seekor gajah. Orang buta pertama mengatakan gajah itu besar sekali karena dia memegang perut gajah. Orang buta kedua mengatakan gajah itu kecil, panjang dan berbulu, karena dia memegang ekor gajah. Lalu orang buta ketiga mengatakan gajah itu tipis dan lebar karena dia memegang kuping gajah.

Keberagaman pandangan dalam hukum merupakan suatu keniscayaan dan mesti disikapi dengan bijaksana. Sebagai seorang sarjana hukum, kita harus terbiasa dengan perbedaan pendapat. Pandangan yang berbeda 
akan memperkaya khazanah pengetahuan hukum itu sendiri. Perbedaan pendapat salah satunya disebabkan oleh cara menginterpretasikan suatu regulasi dengan metode yang berbeda. Metode penemuan hukum interpetasi merupakan salah satu cara untuk menjawab persoalan hukum.

Ada beragam metode interpretasi yang berkembang dalam ilmu hukum. Mulai interpretasi gramatikal, otentik, teleologis, sismatis, historis, komparatif, futuristis, reskriktif dan ekstensif. Semua metode interpretasi ini dapat menghasilkan padangan yang berbeda. Berikut penjelasan terkait macam-macam interpretasi, yaitu (Mertokusumo, 2010: 220-225).

1) Interpretasi gramatikal adalah penafsiran atas sebuah aturan menurut bahasa, misalnya frasa "menggelapkan barang" dalam Kitab Undang-Undang Hukum Pidana (KUHP) dimaknai secara bahasa dimaknai "mencuri barang yang dipercayakan kepadanya”.

2) Interpretasi otentik adalah penafsiran berdasarkan batasan yang dicantumkan dalam peraturan itu sendiri, biasanya terdapat pada bagian penjelasan.

3) Interpretasi teleologis (sosiologis) adalah penafsiran berdasarkan tujuan masyarakat.

4) Interpretasi sistematis (logis) adalah penafsiran dengan mengaitkan peraturan satu dengan peraturan lainya. Contohnya makna akta otentik yang terdapat dalam UndangUndang Jabatan Notaris bisa dikaitkan dengan Pasal 1868 Kitab Undang-Undang Hukum Perdata yang memberikan penjelasan apa itu akta otentik.

5) Interpretasi historis adalah penafsiran dengan menyimak latar belakang sejarah hukum atau sejarah perumusan suatu ketentuan tertentu.

6) Interpretasi komparatif adalah membandingkan aturan sistem hukum yang satu dengan aturan yang ada pada sistem hukum lainya.

7) Interpretasi futuristis adalah penafsiran dengan mengacu pada Rancangan Peraturan Perundang-Undangan atau 
rumusan yang dicita-citakan (ius constituendum).

8) Interpretasi reskriptif adalah penafsiran dengan membatasi/ mempersempit suatu ketentuan.

9) Interpretasi ekstensif adalah penafsiran dengan memperluas cakupan suatu aturan.

Pasal 16 ayat (1) huruf c UUJN yang mengharuskan Notaris untuk melekatkan surat dan dokumen serta sidik jari penghadap pada Minuta Akta. Atas ketentuan tersebut, sempat menimbulkan kekagetan diantara Notaris, karena hal semacam ini merupakan hal yang baru dalam dunia kenotariatan. Seminar, sosialisasi, dan diskusi pun diselenggarakan untuk memahami ketentuan ini, namun keberagaman padangan atas ketentuan ini tidak dapat dielakan. Mulai dari jari yang mana, berapa jari, dan apakah dibubuhkan di kertas minuta atau di kertas yang terpisah dari kertas minuta. Ada lagi yang menafsirkan ketentuan yang menwajibkan melekatkan sidik jari pada minuta akta baru berlaku bila telah memiliki peraturan pelaksana.
Ketentuan melekatkan sidik jari telah berlaku sejak diundangkannya UUJN, karena hal ini memang dinyatakan dengan tegas di dalam Undang-Undang. Selain itu, kewajiban melekatkan sidik jari pada minuta akta, tidak mendelegasikan kepada peraturan dibawahnya untuk diatur lebih lanjut sebagai syarat berlaku efektif. Artinya kewajiban melekatkan sidik jari pada minuta akta secara yuridis telah berlaku tanpa peraturan pelaksana. Mengenai jari yang mana yang harus dibubuhkan dan berapa jumlah jarinya, bagi penulis hal itu tidak lah menjadi masalah, mau satu jari jempol, keduanya atau malah kesepuluh jari tangan, menurut penulis hal itu sama saja, karena Undang-Undang hanya mengatur melekatkan sidik jari dan tidak mengatur berapa jari dan jari yang mana yang harus dibubuhkan.

Apakah sidik jari dibubuhkan langsung pada minuta akta atau dalam kertas yang terpisah dari minuta akta? Kebanyakan yang berkembang dikalangan Notaris adalah dengan menggunkan kertas yang terpisah dari minuta akta. Lalu 
kertas yang berisi sidik jari penghadap itu dilekatkan pada minuta akta. Namun ada juga yang membubuhkan sidik jari tersebut langsung pada kertas minuta akta.

Bagi penulis, perbedaan ini tidak lah masalah, karena hakekat dari kewajiban melekatkan sidik jari telah tercapai walau ada perbedaan pada kertas mana sidik jari itu dibubuhkan. Perintah melekatkan sidik jari bertujuan untuk menegaskan dan membuktikan bahwa penghadap benar-benar telah hadir di hadapan Notaris.

Mesti diakui bahwa sebuah regulasi yang baik adalah regulasi yang mempersempit terjadinya multitafsir. Keberagaman interpretasi akan menyim-pulkan implementasi yang berbeda-beda pula. Untuk mengakhiri perbedaan tafsir terkait kewajiban melekat sidik jari pada minuta akta, maka perlu dibuat suatu aturan pelaksana yang mengatur kewajiban melekatkan sidik jari pada minuta akta (Dharma, 2015 : 6). Oleh karena undang-undang tidak mendelegasikan kepada peraturan dibawahnya mengenai kewajiban tersebut untuk diatur lebih lanjut dalam bentuk peraturan apa, maka regulasi yang paling tepat untuk mengaturnya lebih lanjut adalah Peraturan Pemerintah (PP). Hal ini sesuai dengan apa yang telah diatur dalam Pasal 12 Undang-Undang No. 12 Tahun 2011 tentang Pembentukan Peraturan Perundang-Undangan, "Materi muatan Peraturan Pemerintah berisi materi untuk menjalankan Undang-Undang sebagaimana mestinya."

Kekuatan Pembuktian Minuta Akta Notaris Tanpa Pelekatan Sidik Jari Para Penghadap

Pelekatan sidik jari oleh Notaris dalam minuta akta adalah wajib hukumnya. Namun pertanyaan yang mendasar adalah apa movitasi/latar belakang pelekatan sidik jari ini ke dalam akta. Berdasarkan tradisi, pelekatan cap jempol hanya dilakukan untuk akta-akta yang tidak dapat ditandatangani oleh penghadapnya, mungkin karena kondisi fisik maupun lantaran penghadap tak dapat menyatakan tandatangannya. Kalau memang pelekatan sidik jari untuk membuktikan bahwa penghadap benar-benar menghadap notaris dan 
menyetujui isi akta, maka pertanyaan selanjutnya adalah mengapa harus dilembar tersendiri, bukankah lebih otentik kalau pada lembar akta itu sendiri, serta lantas bagaimanakah kekuatan pembuktiannya.

Dalam menilai sebuah akta akta Notaris harus didasarkan pada 3 (tiga) nilai pembuktian, yaitu: (Harahap. 2015: 655)

\section{Kekuatan Pembuktian Lahiriah (uitwendige bewijskracht)}

Kemampuan lahiriah akta

Notaris, merupakan kemampuan akta itu sendiri untuk membuktikan keabsahannya sebagai akta otentik (acta publica probant sese ipsa). Jika dilihat dari luar (lahirnya) sebagai akta otentik serta sesuai dengan aturan hukum yang sudah ditentukan mengenai syarat akta otentik, maka akta tersebut berlaku sebagai akta otentik, sampai terbukti sebaliknya, artinya sampai ada yang membuktikan bahwa akta tersebut bukan akta otentik secara lahiriah. Dalam hal ini beban pembuktian ada pihak yang menyangkalnya keotentikan akta Notaris. Parameter untuk menentukan akta Notaris sebagai akta otentik, yaitu tanda tangan dari Notaris yang bersangkutan, baik yang ada pada Minuta dan Salinan dan adanya awal akta (mulai dari judul) sampai dengan akhir akta.

Nilai pembuktian akta Notaris dari aspek lahiriah, akta tersebut harus dilihat apa adanya, bukan dilihat ada apa. Secara lahiriah tidak perlu dipertentangkan dengan alat bukti yang lainnya. Jika ada yang menilai bahwa suatu akta Notaris tidak memenuhi syarat sebagai akta, maka yang bersangkutan wajib untuk membuktikan bahwa akta tersebut secara lahiriah bukan merupakan akta otentik.

\section{Kekuatan Pembuktian Formal (formele bewijskracht)}

Akta Notaris harus memberikan kepastian bahwa sesuatu kejadian dan fakta tersebut dalam akta betulbetul dilakukan oleh Notaris atau diterangkan oleh pihak-pihak yang menghadap pada saat yang tercantum dalam akta sesuai dengan prosedur yang sudah ditentukan dalam dalam pembuatan akta. (Harahap, 2015: 567). Secara formal untuk membuktikan kebenaran dan kepastian tentang hari, tanggal, 
bulan, tahun, pukul (waktu) menghadap, dan para pihak yang menghadap, paraf dan tanda tangan para pihak/penghadap, saksi dan Notaris, serta membuktikan apa yang dilihat, disaksikan, didengar oleh Notaris (pada akta pejabat/berita acara), dan mencatatkan keterangan atau pernyataan para pihak atau penghadap (pada akta pihak).

Jika aspek formal yang menjadi permasalahan oleh para pihak, maka harus dibuktikan dari formalitas dari akta, yaitu harus dapat membuktikan ketidakbenaran hari, tanggal, bulan, tahun dan pukul menghadap, membuktikan ketidakbenaran mereka yang menghadap, membuktikan ketidakbenaran apa yang dilihat, disaksikan dan didengar oleh Notaris, juga harus dapat untuk membuktikan ketidakbenaran pernyataan atau keterangan para pihak yang diberikan/disampaikan di hadapan Notaris, dan ketidakbenaran tandatangan para pihak, saksi dan Notaris atauupun ada prosedur pembuatan akta yang tidak dilakukan. Dengan kata lain pihak yang mempermasalahkan akta tersebut harus melakukan

pembuktian terbalik untuk menyangkal aspek formal dari akta Notaris. Jika tidak mampu membuktikan ketidakbenaran tersebut, maka akta tersebut harus diterima oleh siapapun.

\section{Kekuatan Pembuktian Materiil (materiele bewijskracht)}

Merupakan kepastian tentang materi suatu akta, bahwa apa yang tersebut dalam akta merupakan pembuktian yang sah terhadap pihakpihak yang membuat akta atau mereka yang mendapat hak dan berlaku untuk umum, kecuali ada pembuktian sebaliknya. Keterangan atau pernyataan yang dituangkan/ dimuat dalam akta pejabat (atau berita acara), atau keterangan atau para pihak yang diberikan/ disampaikan dihadapan Notaris (akta pihak) dan para pihak harus dinilai benar berkata yang kemudian dituangkan/dimuat dalam akta berlaku sebagai yang benar atau setiap orang yang datang menghadap Notaris yang kemudian atau keterangannya dituangkan atau dimuat dalam akta harus dinilai telah benar berkata. Jika ternyata pernyataan atau keterangan para 
penghadap tersebut menjadi tidak benar berkata, maka hal tersebut tanggungjawab para pihak sendiri.

Notaris terlepas dari hal semacam itu. Dengan demikian, isi akta Notaris mempunyai kepastian sebagai yang sebenarnya, menjadi bukti yang sah untuk/diantara para pihak dan para ahli waris serta para penerima hak mereka. Jika akan membuktikan aspek materil dari akta, maka yang bersangkutan harus dapat membuktikan, bahwa Notaris tidak menerangkan atau menyatakan yang sebenarnya dalam akta (akta pejabat), atau para pihak yang telah benar berkata (di hadapan Notaris) menjadi tidak benar berkata, dan harus dilakukan pembuktian terbalik untuk menyangkal aspek materil dari akta Notaris.

Ketiga aspek tersebut di atas merupakan kesempurnaan akta Notaris sebagai akta otentik dan siapapun terikat oleh akta tersebut. Jika dapat dibuktikan dalam suatu persidangan pengadilan, bahwa ada salah satu aspek tersebut tidak benar, maka akta yang bersangkutan hanya mempunyai kekuatan pembuktian sebagai akta di bawah tangan atau akta tersebut di degradasi kekuatan pembuktiannya sebagai akta yang mempunyai kekuatan pembuktian sebagai akta dibawah tangan (Harahap, 2015: 568).

Selain dari ketiga aspek kekuatan pembuktian akta notaris (otentik), juga ada nilai pembuktian dari akta otentik dalam putusan pengadilan. Dalam praktik, pembuatan akta Notaris ketiga aspek kekuatan pembuktian tersebut tidak dapat dipisahkan satu aspek dengan yang lainnya, tapi dari harus dilihat secara keseluruhan sebagai bentuk penilaian pembuktian atas keotentikan akta Notaris. Nilai pembuktian tersebut dapat dikaji dari beberapa putusan perkara pidana dan perkara perdata yang sesuai dengan ketiga aspek tersebut.

Aspek lahiriah dari akta Notaris dalam yurisprudensi Mahkamah Agung bahwa akta Notaris sebagai alat bukti berkaitan dengan tugas pelaksanaan tugas jabatan Notaris, contohnya Putusan Mahkamah Agung No. 702 K/Sip/1973, tanggal 5 September 1973, yang menegaskan bahwa judex factie dalam amar putusannya membatalkan Akta 
Notaris, hal ini tidak dapat dibenarkan, karena Pejabat Notaris fungsinya hanya mencatatkan apaapa yang dikehendaki dan dikemukakan oleh para pihak yang menghadap Notaris tersebut. Tidak ada kewajiban bagi Notaris untuk menyelidiki secara materil apa-apa (hal-hal) yang dikemukakan oleh penghadap Notaris tersebut. Berdasarkan pada putusan Mahkamah Agung tersebut dapat disimpulkan bahwa (Adjie, 2014: 136) :

1) Akta Notaris tidak dapat dibatalkan.

2) Fungsi Notaris hanya mencatatkan (menuliskan) apaapa yang dikehendaki dan dikemukakan oleh para pihak yang menghadap Notaris tersebut.

3) Tidak ada kewajiban bagi Notaris untuk menyelidiki secara materil apa-apa (hal-hal) yang dikemukakan oleh penghadap tersebut. Dengan demikian bertentangan dengan inti dari akta Notaris, jika akta Notaris yang dibuat atas kehendak para pihak dibatalkan oleh putusan pengadilan, tanpa ada gugatan dari para pihak yang tersebut dalam akta untuk membatalkan akta Notaris.

Pembatalan akta Notaris hanya dapat dilakukan oleh para pihak sendiri.

Akta Notaris berisi keterangan, pernyataan para pihak dan dibuat atas kehendak atau permintaan para pihak, dan Notaris membuatnya dalam bentuk yang sudah ditentukan menurut undang-undang, dan juga Notaris bukan pihak dalam akta tersebut, pencantuman nama Notaris dalam akta karena perintah undangundang. Membatalkan akta Notaris berarti secara lahiriah tidak mengakui akta tersebut, dengan demikian akta tersebut bukan akta Notaris. Penilaian akta Notaris secara lahiriah bukan suatu akta Notaris, maka harus dibuktikan dari awal sampai dengan akhir akta Notaris ada yang tidak dipenuhi syarat mengenai bentuk akta Notaris. Jika dapat dibuktikan bahwa akta Notaris tersebut tidak memenuhi syarat sebagai sebuah akta Notaris, maka tersebut akan mempunyai nilai pembuktian sebagaimana akta 
dibawah tangan, yang penilaian pembuktiannya tergantung kepada pengakuan para pihak dan hakim.

Perkara pidana dan perdata akta Notaris senantiasa dipermasalahkan dari aspek formal terutama mengenai (Adjie, 2014: 136) :

a) kepastian hari, tanggal, bulan, tahun dan pukul menghadap.

b) pihak (siapa) yang menghadap Notaris.

c) tanda tangan yang menghadap.

d) salinan akta tidak sesuai dengan minuta akta,

e) salinan akta ada, tanpa dibuat minuta akta.

f) minuta akta tidak ditandatangani secara lengkap, tapi minuta akta dikeluarkan.

Perkara pidana yang berkaitan dengan aspek formal akta Notaris, pihak penyidik, penuntut umum dan hakim akan memasukkan Notaris telah melakukan tindakan hukum seperti (Adjie, 2014: 136) :

1) membuat surat palsu/yang dipalsukan dan menggunakan surat palsu/yang dipalsukan (Pasal 263 ayat (1), (2) KUHP.

2) melakukan pemalsuan (Pasal 264 KUHP).
3) Menyuruh mencantumkan keterangan palsu dalam akta otentik (Pasal 266 KUHP).

4) melakukan, menyuruh melakukan, yang turut serta melakukan (Pasal 55 jo Pasal 263 ayat (1) dan (2) atau 264 atau 266 KUHP.

5) membantu membuat surat palsu/atau yang dipalsukan dan menggunakan surat palsu/yang diplasukan (Pasal 56 ayat (1) dan (2) jo Pasal 263 ayat (1) dan (2) atau 264 atau 266 KUHP.

Notaris wajib menjamin kepastian hari, tanggal, bulan, tahun dan pukul menghadap yang tercantum atau disebutkan pada bagian awal akta Notaris, sebagai bukti bahwa para pihak menghadap dan menandatangani akta pada hari, tanggal, bulan, tahun dan pukul yang tersebut dalam akta dan semua prosedur pembuatan telah dilakukan sesuai aturan hukum yang berlaku dalam hal ini UUJN.

Jika pihak yang tersebut dalam akta merasa menghadap Notaris dan menandatangani akta di hadapan Notaris pada saat yang diyakininya 
benar, tapi ternyata dalam salinan dan minuta akta tidak sesuai dengan kenyataan yang diyakininya, maka pihak yang bersangkutan melakukan tindakan pengingkaran terhadap kepastian hari, tanggal, bulan, tahun dan pukul menghadap yang tercantum dalam akta. Dalam kaitan ini diperlukan pembuktian dari pihak yang melakukan pengingkaran tersebut dan Notaris yang bersangkutan. Jika semacam itu dikategorikan sebagai suatu tindak pidana, maka Notaris dikualifikasikan melakukan tindak pidana Pasal 263, 264, 266 jo 55 atau 56 KUHP.

Menurut Putusan Pengadilan Negeri Surabaya, nomor 260/1981/Pidana, tanggal, 1 Januari 1984, Pengadilan Tinggi Surabaya, nomor 127/Pid/1984/PT. Sby, tanggal 5 Juli 1984 dan Mahkamah Agung nomor 942/Pid/1984, tanggal 28 September 1985, serta Pengadilan Tinggi Surabaya, nomor 270/Pid/1984/PT. Sby, tanggal 14 April 1986 putusan terhadap pokok perkara, bahwa pembuatan akta pihak, Notaris hanya sekedar mengkonstatir saja apa yang diinginkan atau dikehendaki oleh penghadap yang bersangkutan, dengan cara mencatat, kemudian menyusunnya agar sesuai dengan peraturan hukum yang berlaku, dan kalau sudah selesai dengan kehendak penghadap, maka penghadap diminta untuk membubuhkan tanda tangan serta menulis nama terangnya, hal ini merupakan prosedur pembuatan akta Notaris akta pihak.

Jika kemudian ternyata terbukti bahwa yang menghadap Notaris tersebut bukan orang yang sebenarnya atau orang yang mengaku asli, tapi orang yang sebenarnya tidak pernah menghadap Notaris, sehingga menimbulkan kerugian orang yang sebenarnya.

Pertanggungjawaban pidana dalam kejadian seperti tersebut diatas, tidak dapat dibebankan kepada Notaris, karena unsur kesalahannya tidak ada, dan Notaris telah melaksanakan tugas jabatan sesuai aturan hukum yang berlaku, sesuai asas tiada hukum tanpa kesalahan, dan tiada kesalahan yang dilakukan oleh Notaris yang bersangkutan, maka Notaris tersebut harus dilepas dari tuntutan. 
Dalam pembuatan akta pihak ataupun akta relaas harus sesuai dengan tata cara yang sudah ditentukan. Akta pihak Notaris hanya mencatat, dan membuatkan akta atas kehendak, keterangan atau pernyataan para pihak yang kemudian ditandatangani oleh para pihak tersebut, dan dalam akta relaas, berisi pernyataan atau keterangan Notaris sendiri atas apa yang dilihat atau didengarnya, dengan tetap berlandaskan bahwa pembuatan akta relaaspun haru ada permintaan dari para pihak.

Pemeriksaan terhadap Notaris selaku tersangka atau terdakwa harus didasarkan kepada tata cara pembuatan akta Notaris, yaitu ( Adjie, 2014: 138) :

1) melakukan pengenalan terhadap penghadap, berdasarkan identitasnya yang diperlihatkan kepada Notaris;

2) menanyakan, kemudian mendengarkan dan mencermati keinginan atau kehendak para pihak tersebut (tanya - jawab).

3) memeriksa bukti surat yang berkaitan dengan keinginan atau kehendak para pihak tersebut.
4) memberikan saran dan membuat kerangka akta untuk memenuhi keinginan atau kehendak para pihak tersebut.

5) memenuhi segala teknik administratif pembuatan akta Notaris, seperti pembacaan, penandatatanganan, memberikan salinan, dan pemberkasan untuk minuta.

6) melakukan kewajiban lain yang berkaitan dengan pelaksanaan tugas jabatan Notaris.

Dalam memeriksa Notaris yang berkaitan dengan akta yang dibuat atau dibuat oleh Notaris yang bersangkutan, parameternya harus kepada prosedur pembuatan akta Notaris, dalam hal ini UUJN. Jika semua prosedur sudah dilakukan, maka akta yang bersangkutan tetap mengikat mereka yang membuatnya di hadapan Notaris.

Mempidanakan Notaris dengan alasan-alasan pada aspek formal akta, tidak akan membatalkan akta Notaris yang dijadikan objek perkara pidana tersebut. Dengan demikian akta yang bersangkutan tetap mengikat para pihak. Dalam perkara perdata pelanggaran terhadap aspek 
formal dinilai sebagai suatu tindakan melanggar hukum dan hal ini dilakukan dengan mengajukan gugatan terhadap Notaris yang bersangkutan.

Pengingkaran terhadap aspek formal ini harus dilakukan oleh penghadap sendiri, bukan oleh Notaris atau pihak lainnya. Aspek materiil dari akta Notaris, segala hal yang tertuang harus dinilai benar sebagai pernyataan atau keterangan Notaris dalam akta relaas, dan harus dinilai sebagai pernyataan atau keterangan para pihak dalam akta partij (pihak), hal apa saja yang harus ada secara materil dalam akta harus mempunyai batasan tertentu.

Menentukan batasan seperti itu tergantung dari apa yang dilihat, didengar oleh Notaris atau yang dinyatakan, diterangkan oleh para pihak di hadapan Notaris. Mahkamah Agung dengan putusan nomor $1440 \mathrm{~K} / \mathrm{Pdt} / 1996$, tanggal 30 Juni 1998 menegaskan bahwa suatu akta otentik (atau akta di bawah tangan) hanya berisi satu perbuatan hukum. Bila ada akta mengandung dua perbuatan hukum (misalnya pengakuan hutang dan pemberian kuasa untuk menjual), maka akta ini telah melanggar adagium tersebut, dan akta seperti ini tidak memiliki kekuatan eksekusi (executorial title) Pasal 244 HIR, bukan tidak sah.

Dalam praktek Notaris banyak dilakukan beberapa tindakan hukum dibuat dalam satu akta saja, berdasarkan putusan Mahkamah Agung tersebut batasan akta secara materil, yaitu satu akta Notaris harus memuat satu perbuatan hukum saja.

Kehendak penghadap yang tertuang dalam akta secara materil merupakan kehendak atau keinginan para pihak sendiri, bukan kehendak Notaris, dan tugas Notaris hanya memberi saran saja, kalaupun kemudian saran tersebut diikuti dan dituangkan dalam akta, maka hal tersebut tetap merupakan keinginan atau kehendak penghadap sendiri.

Dalam putusan Pengadilan Negeri Jakarta Barat, nomor 102/Pdt/G/1986, tanggal 13 November 1986, Pengadilan Tinggi Daerah Khusus Ibu kota Nomor 16/Pdt/1987, tanggal 21 Pebruari 1987 dan Mahkamah Agung Nomor 
2827/K/Pdt./1987,tanggal

Pebruari 1987, jika penghadap mendalilkan bahwa akta Notaris yang berisi keterangan atau perkataannya di hadapan Notaris, tidak dikehendaki oleh penghadap, kemudian penghadap mengajukan gugatan dengan gugatan untuk membatalkan akta tersebut. Maka hal tersebut harus dapat dibuktikan bahwa akta dibuat dalam keadaan terpaksa, kekhilafan atau penipuan, jika tidak dapat dibuktikan maka gugatan seperti itu harus ditolak, karena dalam hal ini semua prosedur untuk pembuatan akta telah dilakukan oleh Notaris. Jika secara materil isi akta tidak sesuai dengan keinginan penghadap, maka atas hal tersebut dapat diajukan gugatan ke pengadilan, dengan kewajiban untuk membuktikan dalil gugatannya.

Secara materil akta isi akta merupakan keinginan para pihak, tapi dalam keadaan atau dengan alasan tertentu, akta tersebut batal demi hukum, yaitu jika materi akta tersebut bertentangan dengan aturan hukum, sebagaimana tersebut dalam putusan Pengadilan Negeri Surabaya Nomor 80/Pdt.G/1987/PN. Sby, tanggal 30 April 1987, Pengadilan Tinggi Jawa Timur Nomor 58/Pdt/1988/PT. Sby, tanggal 28 Pebruari 1988 dan Mahkamah Agung Nomor 1462 K/Pdt/1989, tanggal 29 November 1993. Dalam hal ini Mahkamah Agung telah membatalkan akta Notaris karena materi akta yang berisi jual-beli sebidang tanah, dengan memberi hak untuk membeli kembali kepada penjual jangka waktu tertentu dan dengan harga tertentu, adalah bertentangan dengan Undang-undang Nomor 5 Tahun 1960 tentang Peraturan Dasar Pokok-pokok Agraria atau UUPA yang tidak mengenal perbuatan hukum seperti itu.

Dengan demikian secara materil akta Notaris tidak mempunyai kekuatan eksekusi dan batal demi hukum dengan putusan pengadilan, jika dalam akta Notaris (Adjie, 2014: 140) :

1) memuat lebih dari 1 (satu) perbuatan atau tindakan hukum.

2) materi akta bertentangan dengan hukum yang mengatur perbuatan atau tindakan hukum tersebut. 
Berdasarkan penjelasan di atas, akta otentik memiliki tiga jenis kekuatan pembuktian, yaitu: kekuatan pembuktian lahiriah, formal dan material. Kini, pelekatan sidik jari sebagai suatu unsur wajib dalam sebuah akta notaris (kekuatan pembuktian lahiriah) yang juga memberikan penegasan bahwa segala apa yang tertulis dalam akta tersebut adalah sesuai dan benar seperti apa adanya, bukan rekayasa dan dapat menjadi alat bukti yang sempurna bagi para pihak.

\section{Simpulan}

Pada prinsipnya pelekatan sidik jari penghadap tidak berpengaruh terhadap otentisitas suatu akta notaris (akta otentik). Syarat akta otentik sebagaimana telah dinyatakan di dalam Pasal 1868 BW dan Pasal 38 UUJN. Adanya kewajiban untuk melekatkan lembar khusus sidik jari penghadap bertujuan untuk melindungi Notaris dari tindakan penyangkalan tanda tangan yang dilakukan oleh penghadap. Ketika suatu saat tanda tangan penghadap itu disangkal oleh penghadap dan digugat ke pengadilan maka dengan adanya lembar sidik penghadap dapat berfungsi sebagai bukti tambahan bahwa penghadap benar berhadapan dengan Notaris untuk membuat akta. Apabila seorang penghadap tidak bersedia membubuhkan sidik jarinya, maka Notaris dapat memberikan penyuluhan hukum kepada penghadap akan pentingnya sidik jari tersebut bagi penghadap itu sendiri maupun bagi Notaris.

Akta notaris sebagai alat bukti yang memiliki pembuktian yang sempurna, pembuktian minuta akta yang dilekati sidik jari dapat memperkuat pembuktian mengenai pembuatan suatu akta otentik agar para pihak tidak dengan mudahnya lagi untuk melakukan pembantahan atas kehadiran, pembuatan dan penandatanganan akta tersebut dan dengan adanya pelekatan sidik jari ini juga dapat dipakai untuk membantah sanggahan yang dilakukan oleh pihak yang beritikad tidak baik. Kedua, Mengenai adanya ketidaksamaan antara sidik jari dan penghadap ini mengindikasikan adanya pemalsuan dokumen pada saat para pihak menghadap kepada notaris untuk pembuatan akta yakni 
dokumen yang berupa KTP (kartu tanda penduduk) sebab tidak akan terjadi ketidaksamaan pada sidik jari apabila KTP yang digunakan adalah yang sebenarnya. Jadi, Notaris harus melaksanakan kewajiban untuk melekatkan sidik jari penghadap, karena merupakan bentuk perlindungan hukum bagi Notaris terhadap tindakan penyangkalan tanda tangan oleh penghadap.

Pentingnya sidik jari penghadap adalah dalam rangka kepastian hadirnya penghadap dan tambahan alat bukti. Mengenai bagaimana jika para penghadap menolak melekatkan sidik jari, karena bisa saja terjadi hal yang demikian, maka langkah notaris harus memberi alasan penolakan pelekatan sidik jari diminuta akta pada penutup aktanya. Meskipun akta tersebut tanpa adanya sidik jari dari penghadap akta tetap autentik dan tidak terdegradasi menjadi akta di bawah tangan. Di sisi lain perlu diingat sebagaimana tercantum dalam Pasal 16 ayat 11 UndangUndang Nomor 2 Tahun 2014 Tentang Perubahan Atas UndangUndang Nomor 30 Tahun 2004 Tentang Jabatan Notaris, jika notaris tidak melekatkan sidik jari para penghadap diminuta akta maka notaris akan mendapatkan sanksi berupa peringatan tertulis, pemberhentian sementara, pemberhentian dengan hormat dan pemberhentian dengan tidak hormat oleh Majelis Pengawas.

\section{Daftar Pustaka}

\section{Buku}

Adjie, Habib. 2014. Hukum Notaris Indonesia, Bandung: Refika Aditama

Departemen Pendidikan Nasional, 2008. Kamus Bahasa Indonesia, Jakarta: Pusat Bahasa

Harahap, M. Yahya. 2015. Hukum Acara Perdata, Jakarta: Sinar Grafika

Mertokusumo, Sudikno. 2010. Mengenal Hukum, Yogyakarta: Cahaya Atma Pustaka

\section{Karya Ilmiah}

Danan Suka Dharma, Agustinus. (2015). Pelekatan Sidik Jari Penghadap Pada Minuta Akta Notaris Dalam Kaitannya Dengan Kekuatan Pembuktian Akta Otentik, Tesis, Magister Kenotariatan Fakultas Hukum Universitas Sebelah Maret, Surakarta 


\section{Internet}

Indonesia Notary Community (2017)

[Diakses tanggal 31

Desember 2017].

http://www.indonesianotaryc

ommunity.com/menilai-

pembuktian-akta-otentik/

Indonesia Notary Community (2017)

[Diakses tanggal 31

Desember 2017].

http://www.indonesianotaryc

ommunity.com/mempeributk

an-sidik-jari/

Hukum Online [Diakses tanggal 31

Desember 2017]

http://www.hukumonline.com /berita/baca/lt52f8ed03d67c9/ aturan-kewajiban-sidik-jari-

di-uu-bikin-bingung-notaris

Hukum Online [Diakses tanggal 31

Desember 2017]

http://www.hukumonline.com /berita/baca/lt5332b34c4dc5a /ini-tegaskan-sidik-jaricukup-jempol-kanan 